\title{
Correlation Between Nongenomic Action of C19-Steroids and COVID-19 Severity
}

\section{Mercedes PERUSQUÍA ${ }^{1}$}

${ }^{1}$ Departamento de Biología Celular y Fisiología, Instituto de Investigaciones Biomédicas, Universidad Nacional Autónoma de México, Ciudad de México, México

Received August 17, 2021

Accepted September 29, 2021

\section{Summary}

The recent COVID-19 pandemic is the defining global health crisis of our time and little is known about this disease. It has been reported that advanced age is considered a major risk factor for COVID-19 complications, and data suggest that this disease is deadlier for men than women but these observations are currently unclear. Regarding androgen action, it has been shown that certain smooth muscles are a target for androgens by inducing an acute relaxing effect in airway and vascular tissues that is nongenomically mediated; likewise, androgens are capable of inducing genomic anti-inflammatory and nongenomic hypotensive responses. The aim of this report is to associate the relationship between COVID-19 and aging men as well as the comorbidities presented in this group of patients linked with androgen deficiency. Remarkably, the nongenomic mechanisms of androgens as potential protectors are reviewed. On this basis, it is suggested that hypotestosteronemia may be a risk factor for COVID-19 severity.

\section{Key words}

Androgens - COVID-19 severity - Male sex steroids • Nongenomic actions $\bullet$ Coronavirus infection

\section{Corresponding author}

M. Perusquía, Department of Cell Biology and Physiology, Institute for Biomedical Research, P.O. Box: 70228, National Autonomous University of Mexico, Mexico City 04510, Mexico. E-mail: perusqui@unam.mx

\section{Introduction}

The SARS-CoV-2 pandemic, which causes coronavirus-induced disease (COVID-19), has spread all over the world. COVID-19 produces upper respiratory tract infections and can progress to severe disease by affecting the lower respiratory tract with dyspnea and severe chest symptoms corresponding to pneumonia. In addition, inflammatory markers, such as C-reactive protein and proinflammatory cytokines are elevated. All these characteristics do not help in oxygenation, contributing to respiratory failure in COVID-19 patients. SARS-CoV-2 acts through the angiotensin-converting enzyme 2 (ACE2) receptor where the novel coronavirus enters the respiratory mucosa. This is, in fact, a key component for the pathogenesis of COVID-19 (for review see Paces et al. 2020). Moreover, androgens that mediate viral entry in the cell (TMPRSS2; transmembrane protease, serin2) have been recognized (Goren et al. 2020, Wambier and Goren 2020). The first biologic step required for potential infectivity of SARS$\mathrm{CoV}-2$ is the priming of the spike proteins by TMPRSS2 (revised by McCoy et al. 2021), whose expression is associated with an increase in androgen receptor (AR) expression (Mikkonen et al. 2010). Therefore, the current evidence of blocking AR by antiandrogens (AR antagonists) during COVID-19 in hospitalized patients shows an important reduction in mortality (McCoy et al. 2021).

It has been reported that diabetes, hypertension, chronic respiratory diseases, and other cardiovascular and cerebrovascular diseases are major risk factors for patients with COVID-19 (Huang et al. 2020, Chen et al. 2020b, Liu et al. 2020). The most common comorbidities reported are: hypertension $56.6 \%$, obesity $41.7 \%$ and 
diabetes $33.8 \%$ (Richardson et al. 2020). It is also important to highlight that the death rate is higher in people aged above 80 and those having comorbid conditions, with at least one comorbidity. In this respect, older age and comorbidities are associated with higher severity and mortality in regard to COVID-19 illness.

It has also been observed that men tend to develop more serious cases than women. It has been reported that men have a threefold higher odds of lethality than women (Porcheddu et al. 2020) with a worldwide average male/female sex ratio of 2 (mostly in the 70-89 age group). Indeed, these data establish a clear sexual dimorphism in the development of COVID-19 (Jin et al. 2020). Nevertheless, the endocrine status in women, such as pregnancy, could be a risk factor for COVID-19 severity because pregnant women are more susceptible to infectious disease due to immune suppression during pregnancy. Additionally, during pregnancy the reduction in total lung capacity and inability to clear secretions can make pregnant women more susceptible to severe respiratory infections. Despite numerous studies, it is difficult to draw absolute conclusions on whether pregnant women are at increased risk of severe consequences of COVID-19 (Mikkonen et al. 2010).

Moreover, the available information has described that the clinical symptoms of COVID-19 in pregnancy were not significantly different from those of nonpregnant women (Chen et al. 2020a); reviewed by Panahi et al. (2020). Admittedly, further studies are needed to verify this.

Notably, as previously mentioned, there is limited information describing sexual differences; thus, the aim of this report is to provide an additional point of view to explain these differences on the basis of one's own experimental findings and to review the published literature (including multiple search strategies in MEDLINE with the PubMed interface).

\section{Biological actions of androgens}

Male sex C19-steroids (androgens) are traditionally considered for the maintenance of male sex characteristics, with testosterone being the main androgen. Likewise, testosterone levels decrease with the age of men (for review see Dušková et al. 2020). Considerable evidence exists that the natural aging process estimates testosterone decreases by approximately $10 \%$ every decade after men reach the age of 30 .
The male sex steroids (also called androgens or C19-steroids), traditionally considered for the maintenance of male sex characteristics, have also been documented to have relevant biological actions in bone, muscle, prostate, adipose tissue and the reproductive, cardiovascular, immune, neural and hematopoietic systems (Mooradian et al. 1987, Rana et al. 2014). The responses produced by these male sex steroids have been studied extensively in most of the known biological functions such as: the secondary male sexual characteristics, sexual behavior, spermatogenesis, increment of muscle mass, loss of adipose tissue, prostate growth, prevention of osteoporosis, and action in the haematopoietic, immune and nervous systems, and hair follicles in the skin, emotions and libido (Mooradian et al. 1987, Rana et al. 2014).

In addition to the masculinizing effects of androgens there are also their anabolic properties. It is accepted that TES produces muscle hypertrophy by on creasing fractional muscle protein synthesis (Brodsky et al. 1996, Urban et al. 1995).

Androgens may modify cellular function by both (i) their well-known classical genomic action and (ii) their more recently identified nongenomic mechanisms of action. This last mechanism of action is very rapid, and the effects are not mediated by the classic intracellular AR. Notably, the physiological nongenomic mechanisms of androgens regulate the cardiovascular and respiratory systems, among others. This report focuses on the nongenomic mechanism of action of androgens and their relationship with COVID-19. In this context, any effort to understand the development and critical condition of COVID-19 is of considerable importance and merits continued investigation.

\section{Androgen-induced nongenomic vasorelaxation}

Acute vasorelaxing effects of androgens have been widely documented in a number of isolated vascular beds of various species of mammals including humans; likewise, this acute vasorelaxing effect of androgens has been characterized as nongenomic mechanism of action (revised in Perusquía 2003, Perusquía et al. 2007, Perusquía and Stallone 2010, Kelly and Jones 2013, Lorigo et al. 2020a, Lorigo et al. 2020b). This vasorelaxing effect is not privative of testosterone because testosterone's precursor dehydroepiandrosterone (DHEA) and the $5 \beta$-reduced metabolite of testosterone (5 $\beta$-dihydrotestosterone; $5 \beta$-DHT) elicit a more potent 
vascular relaxation than testosterone itself, and they do not bind to AR and are totally devoid of androgenic properties. Notably, steroids that were previously considered to be insignificant byproducts of metabolism or degradation products have become to be seen as important in physiology and in pathological states (Dušková et al. 2020).

Consequently, vasorelaxation induced by androgens correlates with an increase in blood flow, as testosterone infusion increases coronary artery blood flow in experimental animals and in humans (Webb et al. 1999, English et al. 2000). The acute in vitro vasorelaxation of androgens may also exert regional or systemic hypotensive responses in vivo. Our in vivo experimental contributions in animals have also reported that BP regulation is expected as a consequence of androgen-induced vasorelaxation, and we reported reduced $\mathrm{BP}$ in normotensive and hypertensive rats, as well as observations where hypertension can be developed by orchidectomy in rats and prevented by treatment with testosterone (Perusquía et al. 2015, Perusquía et al. 2017, Perusquía et al. 2018, Perusquía et al. 2019). Androgens are also antihypertensive in females, which was demonstrated in an in vivo rat model of preeclampsia (Perusquía et al. 2018). All of this information confirms that androgen deficiency is linked to an increased prevalence of hypertension and cardiovascular diseases. In addition, a body of work has associated low circulating levels of testosterone with cardiovascular dysfunction, particularly hypertension (Webb et al. 1999, Khaw and Barrett-Connor 1988, Phillips et al. 1994, English et al. 1997, Pugh et al. 2000).

A body of information has also documented that other risk factors for cardiovascular diseases such as hyperinsulinemia, diabetes, functional hypogonadism, obesity, smoking and age are also associated with hypotestosteronemia (revised by English et al. 1997). Low circulating levels of testosterone have been associated with cardiovascular dysfunction, particularly hypertension (Webb et al. 1999, Khaw and BarrettConnor 1988, Phillips et al. 1994, English et al. 1997, Pugh et al. 2000). Taken together, these lines of evidence indicate that the systemic hypotensive response of androgens involves a direct vasodilatory action of the peripheral vasculature which suggests a beneficial physiological role for androgens in cardiovascular regulation; therefore, androgen deficiency clearly indicates a risk factor for hypertension, suggesting that hypertension in older men may be due to the lower androgen levels in patients with hypertension, a comorbidity highly susceptible to COVID-19. Vasodilation also plays an important role in inflammation which is a process that helps defend the body against harmful pathogens and repair damage caused by injury or disease. Notably, in COVID-19, the beneficial response of androgen-induced vasorelaxation may help during the inflammatory process to allow increased blood flow to the affected area.

\section{Nongenomic relaxing effects of androgens in airway smooth muscle}

Asthma severity decreases during adolescence only among males, when androgens start to be secreted; moreover, low testosterone levels in elderly men may exacerbate asthma. Based on this logic, androgens seemingly diminish the severity of asthma symptoms.

More recent findings have provided evidence that DHEA, testosterone and particularly $5 \beta$-DHT, which is devoid of androgenic actions, induce bronchorelaxation and prevent bronchospasm induced by ovalbumin in an animal model of allergic asthma which is mediated by a nongenomic mechanism of action (Espinoza et al. 2013, Montaño et al. 2014), reviewed by Montaño et al. (2020). Importantly, the anti-inflammatory responses of androgens (Traish et al. 2011, Koziol-White et al. 2012) may contribute significantly to the prevention of asthma, reviewed by Montaño et al. (2020).

These studies indicated that androgens are capable of relaxing airway smooth muscle to increase airflow, suggesting the low levels of androgens may contribute drastically to the severity of COVID-19.

Currently, we do not know if COVID-19 is a trigger for asthma exacerbation but salbutamol medication (a $\beta$-adrenergic agonist) which is used to prevent bronchospasm, has been recently used to treat the critical respiratory condition of COVID-19 (Elbeddini et al. 2020). Indeed, the nongenomic bronchorelaxing and preventive bronchospasm effects of androgens plus their genomic anti-inflammatory action may be an alternative to treating the severe phase of the disease. Hence, it is important to note that dexamethasone, acting only as an anti-inflammatory agent, is not the only steroid that has shown promise in the battle against COVID-19. 


\section{Androgen responses characterized nongenomic mechanisms of action}

It is important to highlight that the steroid response latency has been used as an indicator of genomic versus nongenomic mechanisms of action. Therefore, the rapid (1-2 min) and reversible vasorelaxing and bronchorelaxing effects could be explained as a nongenomic (membrane) action (reviewer in Espinoza et al. 2013, Perusquía and Villalón 1999). In addition, the vasodilatory and bronchodilating nongenomic mechanisms of androgens are supported by a wide variety of evidence that shows that androgeninduced vasorelaxation persists a) when testosterone is covalently bound to albumin and cannot cross the cell membrane; b) in the presence of inhibitors of DNA transcription (actinomycin D) or mRNA translation (cycloheximide); c) in the presence of antagonists of androgen receptors (AR) such as flutamide; and d) in AR-deficient testicular-feminized rats (revised in Perusquía and Stallone 2010, Espinoza et al. 2013, Montaño et al. 2014, Perusquía et al. 2012, Bordallo et al. 2008, Kouloumenta et al. 2006). Similarly, androgen-reduced blood pressure and androgenprevented bronchospasm are also characterized as a nongenomic mechanism of action, since the antihypertension and bronchospasm prevention caused by androgens is immediate to their i.v. bolus administration, as well as to their hypotensive response elicited in Tfm rats (male rats with androgen receptor deficiency) (Perusquía et al. 2019, Espinoza et al. 2013, Montaño et al. 2014, Bordallo et al. 2008, Kouloumenta et al. 2006, Hanson et al. 2020).

\section{Relevant findings and what we need to know}

Taking into account the knowledge gained on the nongenomic mechanisms of androgens that do not bind to $\mathrm{AR}$ in the systems involved in COVID-19 development i.e., both in the respiratory and cardiovascular systems, it is important to consider the relevance they have, and such data suggest a potential therapeutic use of C19-steroids as coadjuvant treatment in COVID-19. This information may suggest clues to treat severe COVID-19 in aging men.

Do to their potency and efficacy in inducing vasorelaxing and bronchorelaxing effects, male sex steroids have been named "vasoactive and bronchoactive androgens" (Perusquía and Stallone 2010, Espinoza et al.
2013, Montaño et al. 2014). It is important to note that this series of androgens, DHEA, testosterone and $5 \beta$-DHT are, more potent relaxants than female steroids, estrogens and progestins to induce relaxation in smooth muscles.

The nongenomic mechanisms of androgens are directly exerted on both vascular and airway smooth muscles, an effect independent of vascular endothelium and airway epithelium, respectively. Accordingly, androgen-induced smooth muscle relaxation is mainly attributed to voltage-gated L-type $\mathrm{Ca}^{2+}$ channel blockade (a natural $\mathrm{Ca}^{2+}$ antagonist) (Perusquía and Stallone 2010, Perusquía et al. 2015, Espinoza et al. 2013, Montaño et al. 2008, Montaño et al. 2014, Flores-Soto et al. 2017, Scragg et al. 2007) acting as dihydropyridines used most frequently as antihypertensives. Likewise, it has been documented that TES-induced vasorelaxation may also activate different types of $\mathrm{K}^{+}$channels in some vascular beds (Deenadayalu et al. 2001, Ding and Stallone 2001, Tep-areenan et al. 2002, Seyrek et al. 2007, Seyrek et al. 2011, Cairraö et al. 2008, Yildiz et al. 2009).

It has been noted that older adults accounted for a disproportionate number of severe cases and deaths due to COVID-19 (Wang et al. 2020, Nikolich-Zugich et al. 2020, Onder et al. 2020, Ruan et al. 2020, Shahid et al. 2020, Wu et al. 2020, Zhou et al. 2020). In this respect, it is a priority to consider the significant decline in male sex steroids and its clinical consequences, a conjunction that has been dubbed androgen deficiency in aging males (Morley 2001). Thus, an aging-associated decline in testosterone levels is accompanied by age-related diseases, such as cardiovascular risks, including hypertension, obesity, metabolic syndrome, dyslipidemia, osteoporosis, hypogonadism, urinary incontinence, loss of muscle strength and deterioration of mood with sexual dysfunction, including erectile dysfunction, premature ejaculation and diminished libido (for review see Kelly and Jones 2013, English et al. 2000, Wang et al. 2011, Traish et al. 2009). Taking together this huge body of information, androgens turn out to be a protective shield against COVID-19, which is in agreement with a study that reported that reduction in total testosterone and calculated free testosterone are correlated with high severity of COVID-19 and their low levels have been suggested as novel predictors of poor prognosis in SARSCoV-2 men (Rastrelli et al. 2021). Unfortunately, this study did not associate testosterone levels with age. Later, it was reported that the serum total testosterone level of COVID-19 in the male patients group was significantly 
lower than that of the control group (median, $140 \mathrm{ng} / \mathrm{dl}$; range, 0.21-328, $322 \mathrm{ng} / \mathrm{dl}$; range, median, 125-674, $\mathrm{p}<0.001$, respectively) (Cinislioglu et al. 2021).

Certainly, the genomic mechanism of action of androgens by binding to cytosolic ARs may also play an important role in the protective action of androgens against COVID-19, such as the anti-inflammatory responses of androgens (Traish et al. 2011, Koziol-White et al. 2012); thus, androgens may have a good effect on the so-called "cytokine storm" produced by patients with severe COVID -19. Likewise, several lines of evidence have documented the blockade of AR during COVID-19 as a successful treatment because ACE2 and TMPRSS2 levels in lung and cardiac cells are reduced by antiandrogens, as revised in McCoy et al. (2021).

Because men have a threefold higher odds of lethality than women, one important question is: Why are women less susceptible to COVID-19 infection?

The simple answer may be based on the wellestablished facts that estradiol can cause vasodilation by both estrogen receptor (ERs)-dependent and second messengers (Dubey et al. 2002). It is accepted that female steroids (estrogens and progestins) have a protective effect on the vascular system but are less effective than androgens in inducing nongenomic vasorelaxing (Perusquía et al. 1996, Perusquía et al. 2007) and bronchorelaxing (Perusquía et al. 1997) effects. Therefore, it is tempting to speculate two possible causes: (i) premenopausal women are relatively protected by female sex steroids several years until menopause (approximately 40-50 years old) and (ii) in some populations, the postmenopausal period of women might be protected by the use of hormone replacement therapy (HRT): in fact, androgens such as testosterone or tibolone have been added to HRT to treat sexual dysfunction in postmenopausal women.

Moreover, estrogens are protective against more severe disease than men by downregulating the expression of ACE2 receptors (Schurz et al. 2019). Maleki et al. (2020) reported that the ACE2 gene is located on the $\mathrm{X}$-chromosome. In this respect, the $\mathrm{X}$-chromosome contains a high density of immunerelated genes; consequently, women generally mount stronger innate and adaptive immune responses than men.

On the other hand, theoretically children are not predisposed to COVID-19 infection but recently it has been seen that cases in young children began to rise. In this respect it may be tentatively assumed that the incidence in children might be associated with low testosterone levels during childhood, especially in younger children, and consequently, children both boys and girls are not protected by steroid hormones against COVID-19. This is in line with a multicenter Chinese study where children aged less than 3 years old accounted for the majority of cases (approximately 40) (Zheng et al. 2020). This population of children demands more attention during home care and hospitalization. Similarly, as this is a risk factor during androgen deficiency in aging males, the time when the circulating levels of androgens start to decline. Therefore, it may be carefully concluded that hypotestosteronemia is, indeed, an important factor the for vulnerability of COVID-19 in aging men, and obviously in prostate cancer patients who are receiving androgen deprivation therapy (ADT) as well as in hypogonadal individuals.

The present contribution is, indeed, the first association of COVID-19 and the nongenomic mechanism of action of sex steroid hormones. In addition, very few works have attempted to explain why women are less susceptible to COVID-19.

\section{Conclusions}

The severity of COVID-19 has been explained by numerous arguments. In the present review, it is suggested that physiological androgen levels may represent a protective action against COVID-19 by a nongenomic mechanism of action, such as their i) vasorelaxing and bronchorelaxing effects and subsequently ii) antihypertensive responses and prevention of bronchospasm. In addition, it is relevant to consider the anti-inflammatory property of androgens mediated by genomic mechanisms. Consistent with this suggestion, low circulating levels of androgens are also linked with cardiovascular and respiratory dysfunctions; thus, androgen deficiency may have a detrimental influence on COVID-19 severity. However, further clinical studies are needed to clarify whether androgens could be used to assist COVID-19 patients.

In the same way, children may be predisposed to COVID-19 infection because both aging men and children are suffer hypotestosteronemia. The explanation accounting for the reduced case rate in women may be the protective action of female steroids as well as the use, if any, of HRT during the menopausal period.

In recent times, much information has stunned us about COVID-19. The present reflection gives a bird's eye view about COVID-19 and male sex C19-steroid 
status. Currently, to understand this disease slightly more, it can only hypothesize that the beneficial effects of androgens may defend against COVID-19 severity.

\section{Conflict of Interest}

There is no conflict of interest.

\section{Acknowledgements}

The author thanks Nieves Herrera for organizing the references of this manuscript. This work was supported by Programa de Apoyo a Proyectos de Investigación e Innovación Tecnológica-UNAM (PAPIIT), grant number IN200320.

\section{References}

BORDALLO J, GARCÍA DE BOTO MJ, MEANA C, VELASCO L, BORDALLO MC, SUÁREZ L, CANTABRANA B, SÁNCHEZ M: Modulatory role of endogenous androgens on airway smooth muscle tone in isolated guineapig and bovine trachea; involvement of beta2-adrenoceptors, the polyamine system and external calcium. Eur J Pharmacol 601: 154-162, 2008. https://doi.org/10.1016/j.ejphar.2008.10.039

BRODSKY IG, BALAGOPAL P, NAIR KS: Effects of testosterone replacement on muscle mass and muscle protein synthesis in hypogonadal men-a Clinical Research Center Study. J Clin Endocrinol Metab 81: 3469-3475, 1996. https://doi.org/10.1210/jcem.81.10.8855787

CAIRRAÖ E, ALVAREZ E, SANTOS-SILVA AJ, VERDE I: Potassium channels are involved in testosterone-induced vasorelaxation of human umbilical artery. Naunyn Schmiedebergs Arch Pharmacol 376: 375-383, 2008. https://doi.org/10.1007/s00210-007-0213-3

CHEN H, GUO J, WANG C, LUO F, YU X, ZHANG W, LI J, ZHAO D, XU D, GONG Q, LIAO J, YANG H, HOU W, ZHANG Y: Clinical characteristics and intrauterine vertical transmission potential of COVID-19 infection in nine pregnant women: a retrospective review of medical records. Lancet 395: 809-815, 2020a. https://doi.org/10.1016/S0140-6736(20)30360-3

CHEN N, ZHOU M, DONG X, QU J, GONG F, HAN Y, QIU Y, WANG J, LIU Y, WEI Y, XIA J, YU T, ZHANG X, ZHANG L: Epidemiological and clinical characteristics of 99 cases of 2019 novel coronavirus pneumonia in Wuhan, China: a descriptive study. Lancet 395: 507-513, 2020b. https://doi.org/10.1016/S0140-6736(20)30211-7

CINISLIOGLU AE, CINISLIOGLU N, DEMIRDOGEN SO, SAM E, AKKAS F, ALTAY MS, UTLU M, SEN IA, YILDIRIM F, KARTAL S, AYDIN HR, KARABULUT I, OZBEY I: The relationship of serum testosterone levels with the clinical course and prognosis of COVID-19 disease in male patients: a prospective study. Andrology 1-10, 2021. https://doi.org/10.1111/andr.13081

DEENADAYALU VP, WHITE RE, STALLONE JN, GAO X, GARCIA AJ: Testosterone relaxes coronary arteries by opening the large-conductance, calcium-activated potassium channel. Am J Physiol Heart Circ Physiol 281: H1720-H1727, 2001. https://doi.org/10.1152/ajpheart.2001.281.4.H1720

DING AQ, STALLONE JN: Testosterone-induced relaxation of rat aorta is androgen structure specific and involves K+ channel activation. J Appl Physiol 91: 2742-2750, 2001. https://doi.org/10.1152/jappl.2001.91.6.2742

DUBEY RK, OPARIL S, IMTHURN B, JACKSON EK: Sex hormones and hypertension. Cardiovasc Res 53: 688-708, 2002. https://doi.org/10.1016/s0008-6363(01)00527-2

DUŠKOVÁ M, KOLÁTOROVÁ L, ŠIMKOVÁ M, ŠRÁMKOVÁ M, MALÍKOVÁ M, HORÁČKOVÁ L, VÍTKU J, STÁRKA L: Steroid diagnostics of 21st century in the light of their new roles and analytical tools. Physiol Res 69 (Suppl 2): S193-S203, 2020. https://doi.org/10.33549/physiolres.934517

ELBEDDINI A, TAYEFEHCHAMANI Y, YANG L: Strategies to conserve salbutamol pressurized metered-dose inhaler stock levels amid COVID-19 drug shortage. Drugs Ther Perspect 1-4, 2020. https://doi.org/10.1007/s40267-020-00759-1

ENGLISH KM, STEEDS R, JONES TH, CHANNER KS: Testosterone and coronary heart disease: is there a link? Q J Med 90: 787-791, 1997. https://doi.org/10.1093/qimed/90.12.787

ENGLISH KM, STEEDS RP, JONES TH, DIVER MJ, CHANNER KS: Low-dose transdermal testosterone therapy improves angina threshold in men with chronic stable angina: A randomized, double-blind, placebo-controlled study. Circulation 102: 1906-1911, 2000. https://doi.org/10.1161/01.cir.102.16.1906 
ESPINOZA J, MONTAÑO LM, PERUSQUÍA M: Nongenomic bronchodilating action elicited by dehydroepiandrosterone (DHEA) in a guinea pig asthma model. J Steroid Biochem Mol Biol 138: 174-182, 2013. https://doi.org/10.1016/i.jsbmb.2013.05.009

FLORES-SOTO E, REYES-GARCÍA J, CARBAJAL-GARCÍA A, COMPUZANO-GONZÁLEZ E, PERUSQUÍA M, SOMMER B, MONTAÑO LM: Sex steroids effects on guinea pig airway smooth muscle tone and intracellular Ca2+ basal levels. Mol Cell Endocrinol 439: 444-456, 2017. https://doi.org/10.1016/j.mce.2016.10.004

GOREN A, MCCOY J, WAMBIER CG, VANO-GALVÁN S, SHAPIRO J, DHURAT R, WASHENIK K, LOTTI T: What does androgenetic alopecia have to do with COVID-19? An insight into a potential new therapy. Dermatol Ther 33: e13365, 2020. https://doi.org/10.1111/dth.13365

HANSON AE, PERUSQUÍA M, STALLONE JN: Hypogonadal hypertension in male Sprague-Dawley rats is reninangiotensin system-dependent: role of endogenous androgens. Biol Sex Differ 11: 1-13, 2020. https://doi.org/10.1186/s13293-020-00324-5

HUANG C, WANG Y, LI X, REN L, ZHAO J, HU Y, ZHANG L, FAN G, XU J, GU X, ET AL.: Clinical features of patients infected with 2019 novel coronavirus in Wuhan, China. Lancet 395: 497-506, 2020. https://doi.org/10.1016/S0140-6736(20)30183-5

JIN JM, BAI P, HE W, WU F, LIU XF, HAN DM, LIU S, YANG JK: Gender differences in patients with COVID-19: Focus on severity and mortality. Front Public Health 8: 1-6, 2020. https://doi.org/10.3389/fpubh.2020.00152

KELLY DM, JONES TH: Testosterone: a vascular hormone in health and disease. J Endocrinol 217: R47-R71, 2013. https://doi.org/10.1530/JOE-12-0582

KHAW KT, BARRETT-CONNOR E: Blood pressure and endogenous testosterone in men: an inverse relationship. J Hypertens 6: 329-332, 1988.

KOULOUMENTA V, HATZIEFTHIMIOU A, PARASKEVA E, GOURGOULIANIS K, MOLYVDAS PA: Non-genomic effect of testosterone on airway smooth muscle. Br J Pharmacol 149: 1083-1091, 2006. https://doi.org/10.1038/sj.bjp.0706936

KOZIOL-WHITE CJ, GONCHAROVA EA, CAO G, JOHNSON M, KRYMSKAYA VP, PANETTIERI JR RA: DHEA-S inhibits human neutrophil and human airway smooth muscle migration. Biochim Biophys Acta 1822: 1638-1642, 2012. https://doi.org/10.1016/j.bbadis.2012.06.012

LIU K, FANG YY, DENG Y, LIU W, WANG MF, MA JP, XIAO W, WANG YN, ZHONG MH, LI CH, LI GC, LIU HG: Clinical characteristics of novel coronavirus cases in tertiary hospitals in Hubei Province. Chin Med J (Engl) 133: 1025-1031, 2020. https://doi.org/10.1097/CM9.0000000000000744

LORIGO M, MARIANA M, LEMOS MC, CAIRRAO E: Vascular mechanisms of testosterone: The non-genomic point of view. J Steroid Biochem Mol Biol 196: 105496, 2020a. https://doi.org/10.1016/j.jsbmb.2019.105496

LORIGO M, MARIANA M, OLIVEIRA N, LEMOS MC, CAIRRAO E: Vascular pathways of testosterone: Clinical implications. J Cardiovasc Transl Res 13: 55-72, 2020b. https://doi.org/10.1007/s12265-019-09939-5

MALEKI DANA P, SADOUGHI F, HALLAJZADEH J, ASEMI Z, MANSOURNIA MA, YOUSEFI B, MOMENHERAVI M: An insight into the sex differences in COVID-19 patients: What are the possible causes? Prehosp Disaster Med 35: 438-441, 2020. https://doi.org/10.1017/S1049023X20000837

MCCOY J, GOREN A, CADEGIANI FA, VAÑO-GALVÁN S, KOVACEVIC M, SITUM M, SHAPIRO J, SINCLAIR R, TOSTI A, STANIMIROVIC A, FONSECA D, DORNER E, COSTA ONETY D, ZIMERMAN RA, WAMBIER CG: Proxalutamide Reduces the Rate of Hospitalization for COVID-19 Male Outpatients: A Randomized DoubleBlinded Placebo-Controlled Trial. Front Med 1-7, 2021. https://doi.org/10.3389/fmed.2021.668698

MIKKONEN L, PIHLAJAMAA P, SAHU B, ZHANG FP, JÄNE OA: Androgen receptor and androgen-dependent gene expression in lung. Mol Cell Endocrinol 317: 14-24, 2010. https://doi.org/10.1016/j.mce.2009.12.022

MONTAÑO LM, CALIXTO E, FIGUEROA A, FLORES-SOTO E, CARBAJAL V, PERUSQUÍA M: Relaxation of androgens on rat thoracic aorta: testosterone concentration dependent agonist/antagonist L-type Ca2+ channel activity, and 5b-dihydrotestosterone restricted to L-type Ca2+ channel blockade. Endocrinology 149: 2517-2526, 2008. https://doi.org/10.1210/en.2007-1288

MONTAÑO LM, ESPINOZA J, FLORES-SOTO E, CHÁVEZ J, PERUSQUÍA M: Androgens are bronchoactive drugs that act by relaxing airway smooth muscle and preventing bronchospasm. J Endocrinol 222: 1-13, 2014. https://doi.org/10.1530/JOE-14-0074 
MONTAÑO LM, FLORES-SOTO E, SOMMER B, SOLÍS-CHAGOYÁN H, PERUSQUÍA M: Androgens are effective bronchodilators with anti-inflammatory properties: A potential alternative for asthma therapy. Steroids 153: 108509, 2020. https://doi.org/10.1016/j.steroids.2019.108509

MOORADIAN AD, MORLEY JE, KORENMAN SG: Biological actions of androgens. Endocr Rev 8: 1-28, 1987. https://doi.org/10.1210/edrv-8-1-1

MORLEY JE: Androgens and aging. Maturitas 38: 61-71, 2001. https://doi.org/10.1016/s0378-5122(00)00192-4

NIKOLICH-ZUGICH J, KNOX KS, RIOS CT, NATT B, BHATTACHARYA D, FAIN MJ: SARS-CoV-2 and COVID-19 in older adults: what we may expect regarding pathogenesis, immune responses, and outcomes. Geroscience 42: 505-514, 2020. https://doi.org/10.1007/s11357-020-00186-0

ONDER G, REZZA G, BRUSAFERRO S: Case-Fatality Rate and Characteristics of Patients Dying in Relation to COVID-19 in Italy. JAMA 323: 1775-1776, 2020. https://doi.org/10.1001/jama.2020.4683

PACES J, STRIZOVA Z, SMRZ D, CERNY J: COVID-19 and the immune system. Physiol Res 69: 379-388, 2020. https://doi.org/10.33549/physiolres.934492

PANAHI L, AMIRI M, POUY S: Risks of Novel Coronavirus Disease (COVID-19) in pregnancy; a narrative review. Arch Acad Emerg Med 8: e34, 2020.

PERUSQUÍA M, CONTRERAS D, HERRERA N: Hypotestosteronemia is an important factor for the development of hypertension: elevated blood pressure in orchidectomized conscious rats is reversed by different androgens. Endocrine 65: 416-425, 2019. https://doi.org/10.1007/s12020-019-01978-x

PERUSQUÍA M, ESPINOZA J, MONTAÑOLM, STALLONE JN: Regional differences in the vasorelaxing effects of testosterone and its 5-reduced metabolites in the canine vasculature. Vascul Pharmacol 56: 176-182, 2012. https://doi.org/10.1016/j.vph.2012.01.008

PERUSQUÍA M, FLORES-SOTO E, SOMMER B, CAMPUZANO-GONZÁLEZ E, MARTÍNEZ-VILLA I, MARTÍNEZ-BANDERAS AI, MONTAÑO LM: Testosterone-induced relaxation involves L-type and storeoperated Ca2+ channels blockade, and PGE 2 in guinea pig airway smooth muscle. Pflugers Arch 467: 767-777, 2015. https://doi.org/10.1007/s00424-014-1534-y

PERUSQUÍA M, HANSON AE, MEZA CM, KUBLI C, HERRERA N, STALLONE JN: Antihypertensive responses of vasoactive androgens in an in vivo experimental model of preeclampsia. J Steroid Biochem Mol Biol 178: 65-72, 2018. https://doi.org/10.1016/j.jsbmb.2017.11.001

PERUSQUÍA M, HERNÁNDEZ R, MONTAÑO LM, VILLALÓN CM, CAMPOS MG: Inhibitory effect of sex steroids on guinea-pig airway smooth muscle contractions. Comp Biochem Physiol C Pharmacol Toxicol Endocrinol 118: 5-10, 1997. https://doi.org/10.1016/s0742-8413(97)00029-7

PERUSQUÍA M, HERNÁNDEZ R, MORALES MA, CAMPOS MG, VILLALÓN CM: Role of endothelium in the vasodilating effect of progestins and androgens on the rat thoracic aorta. Gen Pharmacol 27: 181-185, 1996. https://doi.org/10.1016/0306-3623(95)00091-7

PERUSQUÍA M, HERRERA N, FERRER M, STALLONE JN: Antihypertensive effects of androgens in conscious, spontaneously hypertensive rats. J Steroid Biochem Mol Biol 167: 106-114, 2017. https://doi.org/10.1016/j.jsbmb.2016.11.016

PERUSQUÍA M, NAVARRETE E, GONZÁLEZ L, VILLALÓN CM: The modulatory role of androgens and progestins in the induction of vasorelaxation in human umbilical artery. Life Sci 81: 993-1002, 2007. https://doi.org/10.1016/j.lfs.2007.07.024

PERUSQUÍA M, STALLONE JN: Do androgens play a beneficial role in the regulation of vascular tone? Nongenomic vascular effects of testosterone metabolites. Am J Physiol Heart Circ Physiol 298: H1301-H1307, 2010. https://doi.org/10.1152/ajpheart.00753.2009

PERUSQUÍA M, VILLALÓN CM: Possible role of $\mathrm{Ca} 2+$ channels in the vasodilating effect of 5betadihydrotestosterone in rat aorta. Eur J Pharmacol 371: 169-178, 1999. https://doi.org/10.1016/s00142999(99)00161-2

PERUSQUÍA M: Androgen-induced vasorelaxation: a potential vascular protective effect. Exp Clin Endocrinol Diabetes 111: 55-59, 2003. https://doi.org/10.1055/s-2003-39229

PHILLIPS GB, PINKERNELL BH, JING TY: The association of hypotestosteronemia with coronary artery disease in men. Arterioscler Thromb 14: 701-706, 1994. https://doi.org/10.1161/01.atv.14.5.701 
PORCHEDDU R, SERRA C, KELVIN D, KELVIN N, RUBINO S: Similarity in Case Fatality Rates (CFR) of COVID19/SARS-COV-2 in Italy and China. J Infect Dev Ctries 14: 125-128, 2020. https://doi.org/10.3855/jidc.12600

PUGH PJ, ENGLISH KM, JONES TH, CHANNER KS: Testosterone: a natural tonic for the failing heart? Q J Med 93: 689-694, 2000. https://doi.org/10.1093/qjmed/93.10.689

RANA K, DAVEY RA, ZAJAC JD: Human androgen deficiency: insights gained from androgen receptor knockout mouse models. Asian J Androl 6: 169-177, 2014. https://doi.org/10.4103/1008-682X.122590

RASTRELLI G, DI STASI V, INGLESE F, BECCARIA M, GARUTI M, DI COSTANZO D, SPREAFICO F, GRECO GF, CERVI G, PECORIELLO A: Low testosterone levels predict clinical adverse outcomes in SARS-CoV-2 pneumonia patients. Andrology 9: 88-98, 2021. https://doi.org/10.1111/andr.12821

RICHARDSON S, HIRSCH JS, NARASIMHAN M, CRAWFORD JM, MCGINN T, DAVIDSON KW: Presenting Characteristics, Comorbidities, and Outcomes Among 5700 Patients Hospitalized With COVID-19 in the New York City Area. JAMA 323: 2052-2059, 2020. https://doi.org/10.1001/jama.2020.6775

RUAN Q, YANG K, WANG W, JIANG L, SONG J: Clinical predictors of mortality due to COVID-19 based on an analysis of data of 150 patients from Wuhan, China. Intensive Care Med 46: 846-848, 2020. https://doi.org/10.1007/s00134-020-05991-x

SCHURZ H, SALIE M, TROMP G, HOAL EG, KINNEAR CJ, MÖLLER M: The X chromosome and sex-specific effects in infectious disease susceptibility. Hum Genomics 13: 1-12, 2019. https://doi.org/10.1186/s40246-018-0185-Z

SCRAGG JL, DALLAS ML, PEERS C: Molecular requirements for L-type Ca2+ channel blockade by testosterone. Cell Calcium 42: 11-15, 2007. https://doi.org/10.1016/j.ceca.2006.11.003

SEYREK M, IRKILATA HC, VURAL IM, YILDIRIM I, BASAL S, YILDIZ O, DAYANC M: Testosterone relaxes human internal spermatic vein through potassium channel opening action. Urology 78: P233.E1-E5, 2011. https://doi.org/10.1016/j.urology.2011.03.003

SEYREK M, YILDIZ O, ULUSOY HB, YILDIRIM V: Testosterone relaxes isolated human radial artery by potassium channel opening action. J Pharmacol Sci 103: 309-316, 2007. https://doi.org/10.1254/jphs.FP0060883

SHAHID Z, KALAYANAMITRA R, MCCLAFFERTY B, KEPKO D, RAMGOBIN D, PATEL R, AGGARWAL CS, VUNNAM R, SAHU N, BHATT D, JONES K, GOLAMARI R, JAIN R: COVID-19 and older adults: What we know. J Am Geriatr Soc 68: 926-929, 2020. https://doi.org/10.1111/jgs.16472

TEP-AREENAN P, KENDALL DA, RANDALL MD: Testosterone-induced vasorelaxation in the rat mesenteric arterial bed is mediated predominantly via potassium channels. Br J Pharmacol 135: 735-740, 2002. https://doi.org/10.1038/sj.bjp.0704522

TRAISH AM, GUAY A, FEELEY R, SAAD F: The dark side of testosterone deficiency: I. Metabolic syndrome and erectile dysfunction. J Androl 30: 10-22, 2009. https://doi.org/10.2164/jandrol.108.005215

TRAISH AM, KANG HP, SAAD F, GUAY AT: Dehydroepiandrosterone (DHEA)--a precursor steroid or an active hormone in human physiology. J Sex Med 8: 2960-2982, 2011. https://doi.org/10.1111/j.1743-6109.2011.02523.x

URBAN RJ, BODENBURGYH, GILKISON C, FOXWORTH J, COGGAN AR, WOLFE RR, FERRANDO A: Testosterone administration to elderly men increases skeletal muscle strength and protein synthesis. Am J Physiol 269: E820-E826, 1995. https://doi.org/10.1152/ajpendo.1995.269.5.E820

WAMBIER CG, GOREN A: Severe acute respiratory syndrome coronavirus 2 (SARS-CoV-2) infection is likely to be androgen mediated. J Am Acad Dermatol 83: 308-309, 2020. https://doi.org/10.1016/j.jaad.2020.04.032

WANG C, JACKSON G, JONES TH, MATSUMOTO AM, NEHRA A, PERELMAN MA, SWERDLOFF RS, TRAISH A, ZITZMANN M, CUNNINGHAM G: Low testosterone associated with obesity and the metabolic syndrome contributes to sexual dysfunction and cardiovascular disease risk in men with type 2 diabetes. Diabetes Care 34: 1669-1675, 2011. https://doi.org/10.2337/dc10-2339

WANG D, HU B, HU C, ZHU F, LIU X, ZHANG J, WANG B, XIANG H, CHENG Z, XIONG Y, ZHAO Y, LI Y, WANG X, PENG Z: Clinical characteristics of 138 hospitalized patients with 2019 novel coronavirus-infected pneumonia in Wuhan, China. JAMA 323: 1061-1069, 2020. https://doi.org/10.1001/jama.2020.1585

WEBB CM, MCNEILL JG, HAYWARD CS, DE ZEIGLER D, COLLINS P: Effects of testosterone on coronary vasomotor regulation in men with coronary heart disease. Circulation 100: 1690-1696, 1999. https://doi.org/10.1161/01.CIR.100.16.1690 
WU JT, LEUNG K, BUSHMAN M, KISHORE N, NIEHUS R, DE SALAZAR PM, COWLING BJ, LIPSITCH M, LEUNG GM: Estimating clinical severity of COVID-19 from the transmission dynamics in Wuhan, China. Nat Med 26: 506-510, 2020. https://doi.org/10.1038/s41591-020-0822-7

YILDIZ O, SEYREK M, IRKILATA HC, YILDIRIM I, TAHMAZ L, DAYANC M: Testosterone might cause relaxation of human corpus cavernosum by potassium channel opening action. Urology 74: 229-232, 2009. https://doi.org/10.1016/j.urology.2008.12.022

ZHENG F, LIAO C, FAN QH, CHEN H, ZHAO X, XIE Z, LI X, CHEN C, LU X, LIU Z, ET AL.: Clinical Characteristics of Children with Coronavirus Disease 2019 in Hubei, China. Curr Med Sci 40: 275-280, 2020. https://doi.org/10.1007/s11596-020-2172-6

ZHOU F, YU T, DU R, FAN G, LIU Y, LIU Z, XIANG J, WANG Y, SONG B, GU X, ET AL.: Clinical course and risk factors for mortality of adult inpatients with COVID-19 in Wuhan, China: a retrospective cohort study. Lancet 395: 1054-1062, 2020. https://doi.org/10.1016/S0140-6736(20)30566-3 